\title{
LITERATUURSTUDIE INZAKE ENIGE ASPECTEN VAN DE BETEKENIS VAN DE MODERNE ADMINISTRATIEVE TECHNIEK VOOR DE ADMINISTRATIE
}

\author{
door N. J. Groen
}

\section{Inleiding}

De uitgebreide titel van deze literatuurstudie houdt in feite de probleemstelling reeds in zich. Wij kunnen van dag tot dag ervaren dat in de administratieve techniek vorderingen worden gemaakt waarvan alle konsekwenties niet zo gemakkelijk zijn te overzien. Een betrekkelijk gering aantal ,ingewijden" uit het organisatorische kamp kent min of meer de mogelijkheden. De massa der uitvoerende administratieve functionarissen echter is slecht op de hoogte van de vaktechnische ontwikkelingen. De zegswijze „onbekend maakt onbemind" is ook hier van toepassing. Teneinde dus van dit grote aantal direct betrokkenen een meer positieve houding te bereiken tegenover de nieuwe administratieftechnische mogelijkheden is het nuttig de verschillende aspecten die daaraan verbonden zijn eens wat nader te bezien.

De beperking ,enige aspecten" duidt er reeds op dat geen uitputtende behandeling is nagestreefd. In het kader van deze beperkte studie is ook slechts een behandeling van de belangrijkste aspecten mogelijk.

Inzake de wijze van aanpak van deze studie diene het volgende. Uit de vakliteratuur is een zodanige selectie van boeken en tijdschriftartikelen gemaakt dat verwacht mag worden dat daaruit verschillende meningen over de onderscheiden kanten van het vraagstuk zullen blijken. Deze meningen zijn hierna geordend naar enige belangrijke aspecten, hoewel gebleken is dat deze hier en daar in elkaar overgaan.

Wat dienen wij te verstaan onder „moderne administratieve techniek"? Dit zou kunnen voeren tot een discussie over het verschil tussen „mechanisatie” en „automatisering”. Kosten, Oberman en Reinoud ${ }^{1}$ ) analyseren dit verschil diepgaand, doch met Frielink ${ }^{2}$ ) zouden wij willen stellen, dat voor ons onderwerp dit verschil niet van principiële doch van graduele betekenis is. Als „modern” zouden wij willen bestempelen die ontwikkelingen in de administratieve techniek van de laatste tijd die de administratie wezenlijk meer mogelijkheden bieden om haar functie van hulpmiddel voor het bedrijfsbeheer beter te vervullen.

In dit verband beschouwt Frielink de administratie met een aan de techniek ontleende analogie als een terugkoppelingssysteem ter regulering van de gang van zaken in een organisatie. Uit de grondgegevens, geregistreerd bij de produktie, resulteren via de administratieve verwerking van deze gegevens, weer nieuwe informaties die door de leiding gebruikt worden ter correctie van de besturing van het produktie-apparaat.

De nieuwe mogelijkheden die de moderne apparatuur voor de betere vervulling van de administratieve functie moet bieden, moet derhalve gericht zijn op een verbetering van dit terugkoppelingseffect.

Van Belkum/Van der Meer ${ }^{3}$ ) geven in dit verband twee factoren aan, namelijk enerzijds de grotere verwerkingssnelheid van de machines en anderzijds de mogelijkheid van deze machines om tussen moeilijk vergelijkbare alternatieven een verantwoorde keuze te maken door het in aanmerking nemen en wegen 
van alle factoren die van invloed zijn. De bereikte tijdwinst leidt tot actueler gegevens en dus tot sneller beslissen door de leiding. De verdergaande analye en/of synthese van de grondgegevens maakt de oplossing mogelijk van bedrijfseconomische problemen, die vroeger zelfs niet konden worden gesteld. De grote betekenis van de nieuwe administratieve techniek voor het snel en grondig voorbereiden van bedrijfsbeslissingen wordt in de literatuur dan ook allerwege benadrukt.

Zoals te verwachten valt worden deze voordelen ons niet zo maar in de schoot geworpen. De invloed op de organisatiestructuur en de organisatieprocedures in de administratie zal zeer ingrijpend zijn. Kosten, Oberman en Reinoud ${ }^{1}$ ) stellen dat vooral voor de grotere administraties een "complete rethinking" nodig zal zijn. Wat dit precies inhoudt blijkt duidelijk uit de volgende aanhaling uit de NIVE-publikatie „Automatisering in het beeld van onze tijd":

'Men moet de procedures, bijvoorbeeld bij administratieve systemen, zo ontwerpen, dat ze geschikt zijn voor automatisering. Een bestaande administratie met mensen vervangen door een identiek, maar dan zelfwerkend systeem, is meestal tot mislukking gedoemd. Alvorens te automatiseren moet men het administratieve systeem in totaal en in detail opnieuw opzetten. Het gaat dus niet alleen om de zichtbare zelfwerkende apparaten en machines; de vernieuwing van de opdracht brengt soms konsekwenties met zich mee op allerlei andere plaatsen in het eigen bedrijf en in de bedrijven van anderen.'

Willemze ${ }^{4}$ ) wijst erop, dat hieraan nog wel een en ander ontbreekt. Hij zegt:

'Volgens een onderzoek van Diebold's firma zijn praktisch alle computers in Amerika kwantitatief en kwalitatief onderbezet. Wat ontbreekt is juist het principiële denken in systemen, dat noodzakelijk is om los te komen van de gebruikelijke administratieve behandeling en te komen tot de essentiële te verrichten procedures.'

Een gelijkluidende uitspraak kan aangehaald worden van Diebold uit zijn handboek "An evaluation of A.D.P.-experience":

'Computers have been discussed as machines rather than systems, and the impression has been left that the replacement of clerks by machines was a simple, speedy and money-saving operation. Managements which undertook automatic data-processing programs on this basis have been disappointed.'

Resumerend mag worden gesteld, dat voor de administratie en voor de bedrijfsleiding de nieuwe techniek grote mogelijkheden, maar navenante invoeringsmoeilijkheden met zich meebrengt. In het hierna volgende zullen wij de volgende punten behandelen:

- organisatorische aspecten

- economische aspecten

- sociale aspecten

- controle aspecten

In de slotbeschouwing zullen wij trachten de verschillende aspecten kort samen te vatten en de toekomstige ontwikkeling nader beschouwen. 


\section{Organisatorische aspecten}

Als deugdelijk uitgangspunt voor de bespreking van de organisatorische aspecten kan dienen de definitie van het begrip administreren, zoals dit is omschreven in het studieprogramma van het vak Administratieve Organisatie van het NIvA, te weten: administreren is het systematisch vastleggen, verwerken en verstrekken van informatie ten behoeve van het besturen en doen functioneren van een huishouding, en ten behoeve van de verantwoording, die daarover moet worden afgelegd.

Volgens Kosten, Oberman en Reinoud ${ }^{1}$ ) ondergaan de functies van de administratie, zoals deze door Van der Schroeff zijn geformuleerd geen wijziging door het gebruik van de moderne apparatuur. Wel geven zij als belangrijk aan, dat de nieuwere ontwikkelingen het mogelijk zullen maken, dat de administratie verschillende van de genoemde functies beter kan vervullen, doordat de gegevens vlugger en accurater en in betere vorm ter beschikking van de leidinggevende instanties op de verschillende niveaus in een bedrijf kunnen komen.

Frielink ${ }^{2}$ ) is van mening, dat de ontwikkeling van de gedachtengang omtrent de administratieve functie en de ontwikkeling van de technische hulpmiddelen elkaar wèl wederzijds beïnvloeden. Deze ontwikkelingen blijken echter zelden harmonisch te zijn, zowel in de ene als in de andere richting kan een faseverschil optreden. Hij zegt dat nog niet eerder in de geschiedenis van de administratieve organisatie een zó groot verschil bestaan heeft tussen wat technisch mogelijk is en wat in feite wordt toegepast. De apparatuur is thans duidelijk vóór op de gedachtengang, op de ontwikkeling van de idee.

Frielink doelt hier o.a. op de mogelijkheden van de geïntegreerde verwerking van administratieve gegevens en de oplossing van zogenaamde combinatorische problemen. Deze beide onderwerpen komen hierna nog ter sprake.

Als belangrijke wijzigingspunten in de structurele organisatie van de administratie zouden wij hierna willen bespreken 1) de verbouding van de ondernemingsleiding ten opzichte van de administratie, en 2) de wijzigingen in bet organisatiepatroon van de administratie zelf, namelijk de verhouding tussen leidende en uitvoerende arbeid en de kwestie van de centrale of decentrale uitvoering van het werk.

Ad. 1) Hiervóór is reeds meermalen gewezen op de heilzame invloed die de moderne apparatuur heeft ten behoeve van de ondernemingsleiding. Anderzijds blijken er ook factoren werkzaam te zijn die de taak van de leiding verzwaren. Kosten, Oberman en Reinoud ${ }^{1}$ ) halen in dit verband een uitspraak aan van een Engelse conferentie:

'dat tengevolge van het optreden van nog meer specialisten, ook aan de top, een toenemend beroep zou worden gedaan op het vermogen van de centrale leiding om lijn- en stafmensen, dus bevelvoerende leiders en specialisten, eendrachtig en in goede harmonie te doen samenwerken, nog steeds een probleem van de eerste orde in de meeste bedrijven!'

Ook de hierna nog te bespreken overige organisatorische aspecten zullen doen blijken dat de coördinerende taak van de ondernemingsleiding belangrijk wordt verzwaard. 
Een geheel ander aspect dat de ondernemingsleiding raakt is het feit dat tengevolge van de mechanisatie of automatisering alle afdelingen van de onderneming meer afhankelijk worden van de administratie, omdat er een tendentie is naar sterkere centralisatie. Becker and Murphy ${ }^{5}$ ) schrijven het volgende:

'Under mechanization, the central office becomes the headquarters and clearinghouse for all company-activities. The office-manager is the custodian of all vital current information that influences the future success of the company.'

De keerzijde hiervan is dat de administrateur ook een groter verantwoordelijkheid gaat dragen en wel met betrekking tot de correcte gegevensverstrekking. Voorgenoemde schrijvers zeggen:

'He will have to understand more clearly the function and objectives of the company in order to furnish meaningfull data to top management, and to reduce the irrelevant information which may currently be cluttering the desks and brief cases of executives. He will have to supply information in such a form that it will provide answers to what will happen if alternate lines of action are followed.'

Ad. 2) Het organisatiepatroon van de administratie zal door en ten behoeve van de invoering van de nieuwe techniek belangrijke wijzigingen ondergaan. Levin ${ }^{6}$ ) wijst op het ontstaan van cen stafafdeling administratieve organisatie (bij hem genaamd "systemen en methoden"), waarbij dus de organiserende arbeid binnen de administratie wordt gecentraliseerd. Dit is ook niet verwonderlijk omdat voor de verwezenlijking van de administratieve integratie men de mogelijkheid moet hebben over de afdelingsgrenzen heen te kijken.

Mulder en Van Oorschot ${ }^{7}$ ) zeggen hierover:

'Een computer zal zijn invloed op en door de gehele organisatie heen voelbaar moeten maken en kan daardoor aanleiding zijn tot een volkomen hergroepering van taken. Vele van de taken in een onderneming zijn immers in de loop der tijden evenwijdig aan elkaar blijven groeien en zijn nooit met elkaar in verband gebracht, omdat er te weinig overeenstemming bestond ten aanzien van hun respectieve administratief-organisatorische eisen. De flexibiliteit en de capaciteit van een computer maken het echter mogelijk om thans tussen veel administraties relaties te leggen, waaraan voorheen niet kon worden gedacht.'

De staffunctionarissen met de reorganisatie belast moeten wel bijzondere mensen zijn, niet slechts qua opleiding, doch ook en vooral qua karakter. Volgens Becker and Murphy ${ }^{5}$ ) moeten zij een ,constructieve houding” aannemen, welke inhoudt dat zij begrijpend, geduldig, vindingrijk, kritisch en verdraagzaam zijn, dat zij initiatief tonen en samenwerken met de lijnfunctionarissen. De door hen het laatst genoemde eigenschap, namelijk vasthoudendheid, mag de functionaris na het voldoen aan al deze eisen zeker wel niet ontbreken.

Gelukkig ontbreekt ook niet de opwekking aan de lijnfunctionarissen om de nodige medewerking te geven. Een aanhaling van Becker and Murphy ${ }^{5}$ ) is duidelijk genoeg:

'The supervisor must accept the breaking-down of established departmental „barriers” or „fencies”, since integrated data-processing is based 
on a continuous, uninterrupted flow of information. No department can ,sit on" its data to suit its own convenience.'

En verder zeggen zij:

,The supervisor may see some forms which he has designed - and which pride of authorship has kept unaltered through the years - replaced by forms designed by experts from forms-printing concerns. He must understand the reasons for this.'

De chefs van de uitvoerende afdelingen moeten derhalve de filosofie van de nieuwe techniek aanvaarden en enige persoonlijke elementen van hun functie loslaten ten behoeve van het nieuwe systeem.

De tweede wijziging in het structuurpatroon van de administratieve organisatie wordt veroorzaakt door de tendentie dat naarmate de omvang van de administratie-apparatuur groter wordt er ook een neiging zal zijn tot centralisatie van de uitvoerende arbeid.

Overigens betreft dit niet alle uitvoerende arbeid doch uitsluitend het zuiver uitvoerende werk en de routinematige beslissingen, dus het laagwaardige denkwerk. Het nimmer mechaniseerbare beoordelingswerk, dus de interpretatie van de informatie en gebruik van de gegevens, zal het meest doelmatig decentraal kunnen plaatsvinden. Levin ${ }^{6}$ ) zegt hierover:

'Centralisatie van gegevensverwerking, gecombineerd met decentralisatie van het gebruik van informatie zal een doelmatige oplossing kunnen zijn. Electronische rekenmachines maken centralisatie van gegevensverwerking mogelijk op een schaal, die vroeger niet praktisch te verwezenlijken was. Een enkel groot systeem of een combinatie van kleinere systemen op een centraal punt kan een zeer effectieve verwerking van gegevens mogelijk maken voor het gehele bedrijf. Een dergelijke centralisatie vraagt echter vaak kostbare communicatielijnen en het accepteren van een grotere standaardisatie.'

De hiervoor reeds aangekondigde noodzakelijke procedurewijzigingen binnen de administratie zijn een volgend organisatorisch aspect dat wij noodzakelijk moeten bezien. Het betreft hier de dwingende eis tot een uitputtende voorbereiding van de invoering van het nieuwe systeem, welke vooral haar oorzaak vindt in de administratieve integratie. Het is derhalve logisch dat wij eerst het begrip administratieve integratie gaan bespreken.

Frielink ${ }^{2}$ ) geeft hiervan de volgende omschrijving:

'Het zodanig organiseren van de vastlegging en verwerking, dat van één grondgegeven voor een veelheid van doeleinden gebruik gemaakt kan worden.'

Even verder zegt hij:

'De integrale aanpak van de automatisering is gebaseerd op de gedachte dat er in de meeste organisaties slechts een beperkt aantal verschillende soorten van initiërende handelingen is. Indien met de vastlegging in een machinaal leesbare vorm van deze initiërende handelingen kan worden bereikt, dat alles wat hieruit als konsekwentie voortvloeit machinaal kan worden gegenereerd, dan zou de basis voor een geïntegreerde toepassing kunnen zijn gelegd.' 
$\mathrm{Na}$ deze omschrijving van het begrip administratieve integratie is het nuttig direct een aanhaling te laten volgen van Foppe ${ }^{8}$ ):

'Het is een niet zelden voorkomend misverstand te menen, dat de computersystemen, waarvan de werking - uiteraard behoudens het vooraf ingebrachte interne programma - geheel integraal geschiedt zonder meer gelijk te stellen met het begrip ,integrated data-processing”. Wel kan men stellen, dat bij de computer het ideaal van de I.D.P. het dichtst is benaderd. Iedere informatieverwerking waarbij men er in is geslaagd een kleiner of groter deel van de vroeger noodzakelijke menselijke interventie uit te schakelen, kan echter reeds in het genoemde begrip besloten worden geacht.'

Ter verduidelijking van het begrip administratieve integratie is het ook nuttig kennis te nemen van de indeling in vertikale en horizontale integratie (respectievelijk volgtijdige en gelijktijdige) zoals die door Mulder en Van Oorschot ${ }^{7}$ ) wordt aangegeven. Hierover schrijven zij het volgende:

'Op het gebied van ,integrated data-processing" zou men wellicht in afwijking van het normale woordgebruik kunnen spreken over vertikale en horizontale integratie. Vertikale integratie zou dan kunnen worden aangeduid als het uitschakelen van menselijke interventie tussen elkaar opvolgende handelingen en horizontale integratie als het logisch samenvoegen van parallel lopende deelproblemen, waartussen relaties bestaan, tot één verwerkingsverband.'

Hierbij zij aangetekend als voorbeeld, dat van vertikale integratie sprake is bij de overgang van het conventionele ponskaartensysteem op een computersysteem. Horizontale integratie (ook wel genaamd parallelisatie) is bijvoorbeeld reeds aanwezig bij het hand- en machinaal doorschrijfsysteem, waarbij in één handeling verschillende dokumenten ontstaan. Ook de eenmalige vastlegging van basisgegevens in ponskaarten en de daarop volgende verwerking in verschillende richtingen moet onder horizontale integratie worden begrepen. $\mathrm{Bij}$ het computersysteem zijn duidelijk vertikale en horizontale integratie beide aanwezig.

Door Mulder en Van Oorschot ${ }^{7}$ ) zijn de hulpmiddelen om tot administratieve integratie te geraken uitgebreid beschreven, zowel zonder als met toepassing van een computer.

Als voordelen van de administratieve integratie kunnen worden genoemd

- de eenmalige vastlegging van de grondgegevens en het meermalige gebruik daarvan in verschillende richtingen; het voordeel is dus besparing van arbeid en uitsluiting van foutenkansen bij herhaalde vastlegging der grondgegevens.

- het feit dat een complex van werkzaamheden in zijn geheel kan worden uitgevoerd en niet behoeft te worden opgedeeld in deelwerkzaamheden, die tot een versplintering van taken kunnen voeren en bovendien weer coördinatieproblemen scheppen; bijkomende voordelen zijn nog de uitschakeling van fouten bij gegevens-transport en de mogelijkheid tot foutenbeveiliging in het gehele systeem.

Zoals gezegd kan met het computersysteem het volledige voordeel van de integratie in beide richtingen worden bereikt. De keerzijde hiervan is, dat men deze zoete vruchten eerst kan plukken nadat men de moeilijkheden die ver- 
bonden zijn aan de invoering van het computersysteem heeft overwonnen. Het uitputtend gebruik maken van de mogelijkheden van vertikale maar vooral horizontale integratie maakt de invoering tot een uitermate complex vraagstuk. In de literatuur is dan ook in ruime mate aandacht besteed aan de voorbereiding en invoering.

Hetgeen Blazer ${ }^{9}$ ) reeds in 1928 schreef geldt thans en in versterkte mate voor de invoering van het computersysteem. Het gaat hier om de volgende zinsnede:

'Invoering van de ponskaartenmachines vraagt zorgvuldige voorbereiding; zowel bestudering van de eisen van het bedrijf en van de mogelijkheid om spoediger en meer gegevens ter beschikking te hebben om het bedrijf in onderdelen te kunnen beoordelen en te controleren, als van de arbeidsanalyse, teneinde een juist beeld van kosten en besparing te kunnen krijgen.'

Meeuwis ${ }^{10}$ ) zegt het in 1960 nog krachtiger met betrekking tot de thans moderne techniek:

'De ,druk-op-de-knop"-mythe moet worden gecorrigeerd met de verwijzing naar de lange en moeilijke weg welke moet worden afgelegd om automatie tot werkelijkheid te brengen. Het mystieke van automatie moet worden weggenomen door het geven van inzicht in hetgeen wezenlijk plaats vindt, waardoor het zelfstandig denken over de mogelijkheden van het nieuwe en over het gebruik maken ervan wordt bevorderd.'

Inzake de voorbereiding zegt Van Duivenboden ${ }^{11}$ ) dat ook wanneer bij het vooronderzoek een computer „nog niet rendabel” blijkt, er toch belangrijk toeleidend werk verricht kan worden, namelijk:

- voorbereidend efficiency-onderzoek

- voorbereidende training

- voorbereidende mechanisering

- voorbereidende ,integratie"

- voorbereidende studie inzake aanpassing van controletechniek door de accountant

Uit de gedetailleerde beschrijving van hetgeen hij onder elk dezer punten wil verstaan blijkt dat hij een zeer intensieve voorbereiding noodzakelijk acht.

Van Belkum/Van der Meer ${ }^{3}$ ) geven een juiste typering van de computer waarin tevens de verklaring gezocht moet worden voor de intensieve voorbereiding:

'Juist omdat een machine kan denken noch beslissen, is voor improvisaties tijdens de uitvoering geen plaats, zodat aan de voorbereiding veel hogere eisen worden gesteld dan in welk ander systeem ook.'

Matzken ${ }^{12}$ ) wijst nog eens op de reeds eerder genoemde ,complete rethinking", wanneer hij zegt:

'In het geval van de machinale hulpmiddelen is de konsekwentie van een dergelijke benadering (te weten vanuit de conceptie van het bestaande, zonder voldoende open te staan tegenover de mogelijkheden welke het nieuwe als zodanig biedt) dat men de nieuwe machines te veel blijft bezien als een middel om sneller te rekenen of te boeken, terwijl deze machines 
juist vragen om een doelmatig aangepaste organisatie, waardoor het volle profijt van hun mogelijkheden wordt getrokken.'

Wat betreft de aanpak van de voorbereiding is het van belang te wijzen op twee verschillende concepties van aanpak, te weten

- the integrated approach

- the step-by-step method

In 1958 laat Willemze ${ }^{4}$ ) een waarschuwing horen tegen de step-by-step methode, dat wil zeggen, hij acht het gevaarlijk de verschillende opeenvolgende fasen in het proces afzonderlijk te bekijken en eventueel één voor één te gaan automatiseren. Hij bracht deze gedachte mee van het CIOS-congres in $1957 . \mathrm{Hij}$ voegt aan zijn waarschuwing het volgende toe:

'Tijdens de discussie leek hierover verschil van opinie te bestaan, wat echter uiteindelijk resulteerde in een welkome aanvulling: tijdens het vooronderzoek moeten zoveel mogelijk fasen als één geheel behandeld en samenhangend onderzocht worden, opdat later niet automatisering van een volgende fase door die van een voorgaande wordt tegengewerkt.'

Ook Kruisinga ${ }^{13}$ ) pleit in 1959 nog voor de integrale aanpak:

'Teneinde de voordelen van geïntegreerde verwerking van de informatiestroom volledig te verwezenlijken, moet over meerdere afdelingen, soms zelfs over alle bedrijfsafdelingen, worden heengegrepen. Alleen door de zaak op deze wijze aan te vatten - ik zou hier willen spreken van systeemanalyse - kan integratie worden bereikt.'

en iets verder:

'Hij (de organisator) moet niet bij stukjes en beetjes trachten te automatiseren, maar in team-verband een frontale aanval openen op in elkanders verlengde liggende procedures. Dit kost tijd, veel tijd zelfs. Het is echter de enige weg naar succes en economische benutting van de kostbare apparatuur.'

Hij vat alles samen in een laatste waarschuwing:

'De met de apparatuur bereikte resultaten zijn nooit beter dan de organisatie van de informatiestroom toelaat.'

In 1960 zegt Meeuwis ${ }^{10}$ ) hierover:

'In bedoelde periode tot voor enige jaren was de hoogste wijsheid over een „,integrated approach" te spreken. Een aanpak step-by-step in het administratieve veld was wel het ergste, dat op organisatorisch gebied kon worden geponeerd.'

Bij de bespreking van de prae-adviezen geeft hij als zijn mening:

'In ons industrieel bedrijf zien wij de omschakeling naar automatie als een proces, als een aaneenschakeling van veroveringen op het oude, zo mogelijk onder insluiting van de nieuwe mogelijkheden. Wij zullen slechts stap voor stap kunnen voortschrijden, waarbij de grootte van iedere stap en de waarde ervan zal worden bepaald door het menselijk vermogen, zich het nieuwe eigen te maken, om met het nieuwe te werken, om met het nieuwe te leven.'

Meeuwis pleit er zelfs voor om als noodzakelijke tussenstap naar een geslaagde automatisering eerst te mechaniseren, waarbij hij dan voornamelijk 
denkt aan geïntegreerde middelen zoals met ponskaarten en ponsbanden. Hij geeft hiervoor de volgende motieven:

- de betrokkenen komen in aanraking met de dwingende eisen van accuratesse, de vorm en de representatie der gegevens en de discipline met betrekking tot het tijdschema.

- men verkrijgt grondige kennis van analyse-werk en systeem-creatie, dus ervaring voor de werkkrachten van de afdeling administratieve organisatie.

- het dwingende karakter van de geïntegreerde verwerking noodzaakt tot schematiseren en uniformeren, teneinde aansluiting te verkrijgen tussen aangrenzende gebieden in de administratie.

De uniformiteit acht hij zeer belangrijk en hij ziet deze in vier richtingen, te weten

- uniformiteit in systemen,

- uniformiteit ten aanzien van het tijdselement,

- uniformiteit ten aanzien van de machinetaal en

- uniformiteit in terminologie, in de aanduiding, in de codering.

Mulder en Van Oorschot ${ }^{7}$ ) geven onzes inziens een goede synthese inzake het vraagpunt van de integrale aanpak of die bij gedeelten.

Het volgende citaat spreekt daarbij voor zich:

'In tegenstelling tot John Diebold, die de ,company-wide” benadering de enig juiste methode vindt bij het invoeren van automatiseringssystemen, hoort men in Nederland soms stemmen opgaan die de "stapsgewijze” benadering propageren. Persoonlijk geloven wij niet dat één van deze benaderingsmethoden absoluut juist of onjuist is, mits men zich slechts realiseert dat men ten aanzien van een ,stap" aan een minimum is gebonden. Er dient namelijk te worden vastgesteld welke problemen op hun onderlinge samenhang dienen te worden onderzocht en hierbij kan dan mede de technische begrenzing een rol gaan spelen.'

Resumerend mogen we stellen dat de invoering van de nieuwe apparatuur een zodanige problematiek met zich meebrengt, dat een volledige inzet van alle krachten nodig is om dit te bereiken. Frielink ${ }^{2}$ ) zegt hiervan:

'De capaciteit van de nieuwe apparatuur is van een zo geheel andere orde van grootte, dat haar toepassing plotseling mogelijkheden opent, die tevoren zonder verder onderzoek als ondoelmatig moesten worden afgewezen en daarom al reeds niet in de gedachten opkwamen.'

In dit verband stelt Kruisinga ${ }^{13}$ ) dat de invoering niet meer het werk is van één man, doch vereist het samenbrengen van de kennis van een reeks van specialisten, onder wie deskundigen, machinespecialisten, administratief geschoolden en bedrijfstechnici. Hij zegt in dit verband:

'Hier ligt dus een vraagstuk van het organiseren van de communicatie en de samenwerking tussen deze groepen. In verschillende gevallen wordt dit nog onvoldoende aangepakt. Men blijft teveel steunen op commissoriaal overleg en vrijwillige samenwerking, terwijl men de weg zou moeten inslaan van het volledig lichten van de betrokken functionarissen uit hun functies en samenvoeging in zogenaamde "task-forces".' 


\section{Economische aspecten}

De invoering van nieuwe administratief-technische hulpmiddelen in de administratie blijft een kwestie van afwegen van offers en nuttigheid. De offers bestaan enerzijds uit kosten van voorbereiding en invoering en anderzijds uit de kosten van de machines die worden gekocht, gehuurd e.d. Uit Amerika zijn voor deze twee categorieën kosten kernachtige uitdrukkingen komen overwaaien, namelijk de ,soft-ware” en de ,hard-ware”.

Ook de te verkrijgen nuttigheid kan worden ingedeeld in twee categorieën, namelijk binnen de administratie de besparing op kantoorarbeid en buiten de administratie de voordelen door betere en snellere berichtgeving.

Reeds in 1922 toen de eerste mechanisatie-golf over de administratie kwam hield Klijnveld ${ }^{14}$ ) een pleidooi voor de toepassing van de mechanisatie, hij gaf echter reeds op de eerste pagina een waarschuwing:

'Men dient bij de toepassing van nieuwe hulpmiddelen in de administratie er steeds op bedacht te zijn dat men de rentabiliteit der hulpmiddelen rechtmatig beoordeelt, met andere woorden, eerst na praktische proefnemingen, die het hoogste nuttig effect der hulpmiddelen hebben te zien gegeven, berekent, of en eventueel welke besparingen door toepassing der bedoelde hulpmiddelen zullen zijn te verkrijgen, zonder van het bestaande systeem iets in te boeten; integendeel, welke verbeteringen men door toepassing van een en ander in het bestaande systeem verkrijgt.'

Richten wij ons eerst op de kostenkant, dan menen wij ervan te mogen uitgaan dat bekend is, dat elektronische machines zeer kostbaar zijn. Van Belkum /Van der Meer ${ }^{3}$ ) noemen als prijs voor de kleinste machine meer dan $\mathrm{f} 100.000,-$, terwijl voor de grotere machines in miljoenen guldens moet worden gerekend. Wil men de hoge investeringskosten ontgaan en tevens het risico dekken dat men niet met verouderde apparatuur moet blijven werken dan kan men de machines ook huren of men kan zijn werk in service laten uitvoeren door de service-afdelingen van de leveranciers of door die welke door de gebruikers gezamenlijk worden geëxploiteerd. Van deze verschillende mogelijkheden geeft Frielink ${ }^{2}$ ) een interessante beschouwing over de voor- en nadelen.

Ook de ,soft-ware” brengt belangrijke kosten met zich. Willemze ${ }^{4}$ ) zegt: „Een computer kost het dubbele van wat hij kost."

Van de zijde van computerleveranciers is ons bekend, dat zelfs schattingen worden gemaakt van anderhalf tot tweemaal de waarde van de aan te schaffen apparatuur, dus van de zogenaamde ,hard-ware”.

Tegen de achtergrond van deze hoge kosten van de moderne apparatuur moeten dus wel belangrijke voordelen staan wanneer men tot de invoering zal overgaan.

Laubach ${ }^{15}$ ) geeft na gesprekken met functionarissen van een en veertig maatschappijen (twaalf computerfabrikanten en negen en twintig actuele of aanstaande gebruikers) een bloemlezing van de goede verwachtingen van een computer:

- kostenbesparingen

- ontwikkeling van nieuwe informatie

- versnelling van gegevensverwerking 
- nauwkeurigheid

- ruimtebesparing

- publiciteit

- doorvoering van veranderingen in administratieve methoden

Mrs. Smith ${ }^{16}$ ), die in 1959 een literatuurstudie maakte van het sociale aspect van de office-automation, is daarbij eveneens de mening tegengekomen dat ondanks de indrukwekkende kosten van data processing systems, men algemeen van oordeel is, dat toepassing van computers op grote schaal in kantoorfuncties spoediger en sneller voortgang zal vinden dan het gebruik in produktiefuncties. Voor dit laatste worden twee oorzaken aangegeven, namelijk enerzijds zijn de computers (in 1959) voor kantoorgebruik gereed en beproefd, voor fabrieksgebruik zijn nog vele technische problemen te overwinnen, zowel aan de kant van de industrie, als aan de kant van de computerfabrikanten. Anderzijds heeft de industrie reeds een hoge graad van mechanisatie bereikt, waarin reeds enorme bedragen zijn geïnvesteerd; kantoren daarentegen zijn veel minder gemechaniseerd en hoeven dus minder apparatuur af te stoten om plaats te maken voor het modernste.

In de moderne literatuur wordt er alom op gewezen, dat men niet uitsluitend moet streven naar besparing op administratiekosten, omdat dan de nieuwe apparatuur slechts in een gering aantal gevallen voordelig zal zijn. De voordelen moeten schuilen in hetgeen door de snellere en betere informatie kan worden bereikt.

Het is in dit verband aardig een passage aan te halen die Blazer ${ }^{9}$ ) in 1928 schreef, namelijk:

'Men ziet de mechanisatie meestal als een kwestie van kostenbesparing. Natuurlijk zal het dit in vele gevallen zijn maar het is onjuist dit vraagstuk alleen uit het oogpunt van bezuiniging te beschouwen en ik zou dan ook daartegenover willen stellen dat het mogelijk is dat men tot invoering van mechaniseringsmethoden besluit waarbij de kosten daaraan verbonden de daarmede direct te bereiken besparing overtreffen, omdat ze leiden tot een boekhouding die beter dan vóbr de wijziging dient als hulpmiddel der organisatie van de bedrijfshuishouding.'

Iets verderop vat hij het geheel nog eens samen en zegt dan:

'Ik wil dan hier nog eens de nadruk leggen op die verkregen gegevens, want de efficiency ligt niet alleen aan de kant van de kosten maar ook aan die van de opbrengsten.'

De verhoudingen liggen thans niet anders dan toen en er zijn nog vele aanhalingen te doen van dezelfde strekking.

Frielink ${ }^{2}$ ) merkt terecht op, dat men aan zulke uitspraken, die zeer algemeen zijn, in feite niets heeft. Daarna karakteriseert hij een aantal categorieën van toepassingen naar de mate en de oorzaken van hun rentabiliteit, kennelijk om de lezers in de gelegenheid te stellen de eigen situatie daaraan te toetsen.

Hij onderscheidt de volgende vijf mogelijkheden:

1. Rendabele toepassingen van arbeidsintensieve administraties, met een repeterend en schematiseerbaar karakter, waardoor belangrijke besparing van arbeidskosten mogelijk wordt. 
2. Rendabele toepassingen van administraties, waarbij de actualiteit/ accuratesse een grote rol speelt, waardoor in het technische of commerciële vlak voordelen zijn te behalen.

3. Vermoedelijk rendabele toepassingen van administraties, die ter gelegenheid van de automatisering sterk zijn gereorganiseerd, waardoor efficiency-voordelen zijn bereikt.

4. Niet of nauwelijks rendabele toepassingen van administraties, waarbij de automatisering deelsgewijs is ingevoerd, met het doel bij verdere voortzetting integratievoordelen te behalen.

5. Onrendabele toepassingen doen zich zeker voor indien fouten bij de invoering zijn gemaakt door bijvoorbeeld onvoldoende voorafgaande bestudering, onderschatting van voorbereiding op invoering, keuze van een verkeerde leverancier (onvoldoende steun of service in het onderhavige rayon), of door keuze van te kleine apparatuur (onvoldoende mogelijkheid tot integratie).

Indien het al mogelijk blijkt te zijn tevoren dan wel achteraf een evaluatie te maken van de offers en de nuttigheid van de administratie voor en na de reorganisatie, mag men niet zonder meer een eventueel voordelig saldo toerekenen aan de moderne apparatuur. In dit saldo zijn namelijk mede begrepen de rationalisatievoordelen, die bereikbaar waren door een efficiency-beoordeling van de vroegere werkmethode ook wanneer geen nieuwe apparatuur werd ingevoerd. Onder andere Kosten, Oberman en Reinoud ${ }^{1}$ ) wijzen hierop:

'Toch zal ook in die gevallen, dat geen aanmerkelijke vergroting van het administratieve apparaat geprojecteerd wordt, een zorgvuldige vergelijking van de alternatieve administratieve mogelijkheden en de daarbij behorende kosten noodzakelijk zijn. De ervaring in het verleden bijvoorbeeld met de voorgenomen invoering van ponskaartenapparatuur heeft meer dan eens uitgewezen dat onvoldoende vergelijkingen waren getroffen met andere, goedkopere, administratie-methoden en -apparatuur, die hetzelfde of nagenoeg hetzelfde effect konden opleveren.'

\section{Sociale aspecten}

De invloeden op de sociale verhoudingen, veroorzaakt door de invoering van moderne administratieapparatuur, hebben enerzijds betrekking op de werkgelegenheid en anderzijds op de werkomstandigheden. Door hun enorme capaciteit kunnen de machines de arbeid van veel routinewerkers overnemen; voor deze categorie zou de werkgelegenheid dus minder kunnen worden. Anderzijds moeten de machines ontworpen, vervaardigd en onderhouden worden, terwijl ook de invoering en later de bediening van de apparatuur nieuwe arbeidsplaatsen schept. Voorts blijft het beoordelingswerk, verbonden aan de interpretatie van de door de machines gegeven informatie en de aanbeveling van maatregelen die daaruit voortvloeien, bestaan als hoogwaardige kantoorarbeid. Over de totale invloed op de werkgelegenheid zijn de deskundigen tamelijk optimistisch. Het is wellicht interessant enige stemmen hierover uit de literatuur weer te geven.

Mrs. Smith ${ }^{16}$ ) beschrijft de snelle introductie van machines in het kantoor 
in de periode 1900-1950 en de invloed op de personeelsbezetting, namelijk de intrede van vrouwelijk personeel in de kantoren en de toenemende vraag naar routinewerkers voor de bediening van hulp- en boekhoudmachines. In tegenstelling tot de steeds weerkerende angstberichten in de toenmalige pers betreffende vervanging van mensen door machines steeg het kantoorpersoneel enorm in aantal. Als oorzaak hiervan zict zij de ontwikkeling van ,scientific management" en de uitgroei van de functie van de administratie tot hulpmiddel van het bedrijfsbeheer, vooral in de steeds groter wordende ondernemingen. Eveneens noemt zij de enorme toename van de papierlawine in de bedrijven waar dokumenten de eindprodukten vormen, namelijk de verzekeringsmaatschappijen en de banken. De voorspoed tijdens en na de oorlog bezorgde deze bedrijfstakken massa's nieuwe klanten.

Ofschoon de kantooremployé-sector qua bezetting enorm werd uitgebreid bleef er niet alleen een kwantitatief maar vooral een kwalitatief tekort bestaan. Vooral het kwalitatieve tekort ziet zij als éćn van de stimulansen tot ontwikkeling en invoering van de moderne arbeidbesparende apparatuur.

Het effect op de werkgelegenheid beschouwt zij als een verschuiving in de vraag naar kantoorpersoneel, welke drie groepen rakt:

- de groep „verplaatsten”, wier taken zijn overgenomen door de machines; omscholing wordt algemeen geprobeerd, er is echter weinig animo, in het geheel niet bij de vrouwen; bij industriële bedrijven behoorlijke opvangmogelijkheden in de fabriek, niet bij de ,,kantoorintensieve" bedrijven als banken en verzekeringsmaatschappijen.

- de groep ,niet gevraagden”, omdat de platsen, waarin zij zouden kunnen worden tewerkgesteld, zijn vervallen; ook wel genoemd de groep der ,technologisch werkelozen"; deze bevinden zich vooral in de opkomende groep jeugdig vrouwelijk personeel. De oplossing hiervoor ziet zij in drie richtingen, te weten aanvullende opleiding door het plaatsen in het geautomatiseerde bedrijfsleven, overschakeling naar lager betaalde ,white collar" plaatsen (winkelmeisjes), en uitschakeling van een deel van de groep ouder vrouwelijk personeel.

- de groep „computer-technici”, die nodig is voor het programmeren, bedienen en onderhouden van de apparatuur; dit is de nieuwe groep, die voorheen niet bestond.

Mrs. Smith pleit ten behoeve van de groep niet-gevraagden om op de scholen voor voortgezet onderwijs cursussen te geven voor bediening en dergelijke van moderne apparatuur. Ten behoeve van de groep computer-technici pleit zij voor opname in de schoolopleiding van een ruime basiskennis van instrumentatie, servo-mechanisme en hydraulica; de industrie moet dan zorgen voor de gespecialiseerde langdurige praktijkscholing.

Kosten, Oberman en Reinoud ${ }^{1}$ ) zeggen over de werkgelegenheid het volgende:

'Een belangrijk verschijnsel uit een oogpunt van arbeidsverhoudingen is voorts de hierboven vermelde eliminering respectievelijk hergroepering van functies en taken. Herscholing en tewerkstelling bij de nieuwe machines zal vooral voor employés op middelbare leeftijd of ouder moeilijkheden opleveren.' 
Op andere plaatsen vermelden $\mathrm{zij}$, dat er een vermindering van cheffuncties op lagere niveaus te verwachten is en in het algemeen een vèrgaande eliminering van functies en taken, gepaard gaande met een hergroepering van de overblijvende functies en taken. Een prettig effect van deze hergroepering blijkt te zijn dat een deel van het vroegere personeel in belangrijker functies terechtkomt door omscholing, hetgeen men ,upgrading" noemt.

Bavinck ${ }^{17}$ ) zegt dat experts verwachten dat juist in de kantoor-sector de automatie grote successen zal kunnen boeken. Hij vraagt zich daarom af of niet het gevaar bestaat dat in deze sector veel personeel overcompleet zal worden of dat evenals in de industrie ook hier compenserende factoren werkzaam zijn.

Ten eerste constateert hij dat er een groot tekort aan kantooremployés is en dat er een achterstand bestond bij de mechanisatie van kantoorarbeid.

Voorts ziet hij inderdaad compenserende factoren omdat de nieuwe methoden nieuwe mogelijkheden bieden en eenmaal de middelen aanwezig zijnde zal de leiding steeds meer gegevens wensen op grond waarvan men beslissingen kan nemen. Zijns inziens ligt de verwachting daarom voor de hand, dat de werkgelegenheid in absolute zin niet zal dalen, omdat ook de algemene compenserende factoren werken: werktijdverkorting, schooltijdverlenging, veroudering bevolking.

Als tweede sociaal aspect zouden wij de werkomstandigheden onder ogen willen zien.

Als belangrijkste wijzigingen hierin zijn te beschouwen het meer fabrieksmatige karakter van de kantoorarbeid voor zover deze althans met de nieuwe machines gebeurt en anderzijds de tendentie om deze arbeid in ploegendienst te gaan verrichten. Dit laatste wordt veroorzaakt door de hoge kosten van de machine, zodat een rendabele exploitatie veelal slechts bij ploegenarbeid bereikbaar is. Als tweede oorzaak geldt wellicht het feit, dat de economische veroudering van de nieuwe apparatuur sneller gaat dan de technische.

Mrs. Smith ${ }^{16}$ ) constateert het hiervoor vermelde en voegt er (uiteraard in Amerikaanse verhoudingen gedacht) aan toe, dat zij een toename verwacht van het lidmaatschap van de vakverenigingen en eveneens een toenemende bemoeienis van de vakverenigingen met de automatisering. Wat dit laatste betreft, de eis is reeds gesteld dat de „verplaatste” kantoormensen moeten worden omgeschoold.

Mrs. Smith ${ }^{16}$ ) verlangt een wijziging van de wettelijke bepalingen zodat ook vrouwen in ploegendienst mogen werken, teneinde op de arbeidsmarkt volwaardig te kunnen meedingen.

Kosten, Oberman en Reinoud ${ }^{1}$ ) maken melding van een Amerikaanse verzekeringsmaatschappij waar de computerafdeling vijf dagen à vierentwintig uur werkt, terwijl de resterende twee dagen gebruikt worden voor onderhoud. $\mathrm{Zij}$ voegen hieraan toe:

'Hierbij valt op te merken, dat dit meer-ploegenstelsel tot op zekere hoogte minder een probleem is dan het schijnt, omdat een niet onbelangrijk deel van de voorbereiding van het avond- en nachtwerk overdag kan geschieden, waardoor de grootte van de 's nachts tewerkgestelde groep employé's vaak anmerkelijk beperkt kan worden.' 
Tot besluit van dit hoofdstuk vestigen wij nog de aandacht op de noodzaak tot uitgebreide maar vooral vroegtijdige voorlichting van het bij de automatisering betrokken personeel. De angst voor het onbekende kan een tegenwerking oproepen, die de slagingskansen van een object belangrijk kunnen verminderen. Deze angst is vooral te wijten aan de zogenaamde populaire maar niettemin volkomen onjuiste uiteenzettingen via de moderne nieuwsmedia inzake de denkende robots en dergelijke, die in een handomdraai het werk van honderden mensen zouden kunnen verrichten. Door dergelijke voorlichting gaat een belangrijk bevolkingsdeel zich in haar bestaanszekerheid bedreigd gevoelen.

Willemze ${ }^{4}$ ) haalt zeer terecht een uitspraak aan van Diebold op het CIOScongres 1957, namelijk:

'Automation not only presents management with a training problem. Education in the widest possible sense, is the most urgent problem of automation.'

\section{Controle-aspecten}

In het kader van deze studie, zijnde een onderwerp uit de administratieve organisatie, vormt het controle-aspect slechts één van de facetten. Als zodanig kunnen hier slechts de hoofdzaken behandeld worden, ofschoon het onderwerp op zich zovele kanten heeft, dat een geheel afzonderlijke literatuurstudie mogelijk is. Dit werk is reeds gebeurd namens de Stichting Studiecentrum voor Administratieve Automatisering door Frielink, waarbij door systematische behandeling over alle belangrijke punten de nationale en internationale meningen tegenover elkaar zijn gesteld.

Blazer ${ }^{9}$ ) heeft vanuit de Nederlandse opvattingen het probleem het eerst besproken op de Accountantsdag 1928. Hij behandelt de invloed van het gebruik van machinale hulpmiddelen op de controle, ingedeeld in drie onderdelen, namelijk de accuratesse-controle, de interne controle en de externe (accountants-) controle.

Veel van het door hem gestelde heeft ook thans nog gelding voor de moderne administratieve techniek, doch het meest bekend is zijn uitspraak inzake de externe controle, die welhaast een gevleugeld woord is geworden:

'De dechargerende arbeid van de accountantscontrole staat in geen verband met de middelen waarvan het beheer zich bij zijn administratie bedient.'

Hij stelt dus dat de doelstelling van de accountantscontrole onveranderd blijft, doch dat de controletechniek zich moet aanpassen aan de administratieve techniek. $\mathrm{Na}$ het vermelden van deze grondstelling willen wij, gezien de beperktheid van ons onderwerp, verder afzien van de externe controle en ons uitsluitend richten op de interne controle.

Kosten, Oberman en Reinoud ${ }^{1}$ ) kunnen in 1956 de problematiek nog niet geheel overzien, doch achten het waarschijnlijk dat met de machinesystemen een veel grotere accuratesse kan worden bereikt dan met de overwegend manuale systemen. $\mathrm{Zij}$ vermelden dat bij een verzekeringsmaatschappij een Univac een jaar lang gedurende vijf dagen a vierentwintig uur premiekwitanties vervaardigde, zonder dat daarbij een fout onbemerkt was gebleven. 
Levin ${ }^{6}$ ) schrijft, dat vastgesteld is dat de mens ongeveer één fout maakt op duizend verwerkte cijfers, ponskaartenmachines één op één miljoen en elektronische rekenautomaten één op honderdbiljoen. Kort daarop laat hij echter volgen:

'Van groot belang voor de administrateur is het feit dat bij gebruik van rekenmachines de controles in handen van een betrekkelijk gering aantal mensen wordt gelegd. Bij de orthodoxe administratieve systemen worden series controles en dwarstellingen gemaakt, die alleen door het samenspannen van een aantal mensen ontweken kunnen worden. Bij een geïntegreerd elektronisch systeem kunnen deze controles overgedragen worden aan één persoon, waardoor de mogelijkheden voor fraudes worden vergroot. Het is daarom van essentieel belang, dat administratieve controles vastgesteld worden over de gehele bewerking. Een juiste planning van het systeem moet leiden tot voldoende controles aangepast aan de grote capaciteit en de soepelheid van de machine.'

Ook de mening van Kosten, Oberman en Reinoud ${ }^{1}$ ) is in dit verband interessant:

'De elektronische techniek nu maakt het mogelijk in de apparatuur checks op iedere bewerking afzonderlijk te verrichten, door een ingebouwd orgaan. Zodra de machine maar een enkele fout maakt, stopt zij ogenblikkelijk. Door de interne foutenbeveiliging is het bijhouden van contrarollen eigenlijk slechts nodig voor:

a. het waken tegen fouten van de mens bij het invoeren van de gegevens,

b. het waken tegen fraude, daar, waar een frauduleus ingrijpen mogelijk is; in zeer ver geïntegreerde en zeer snelle machinesystemen is deze mogelijkheid tamelijk klein.

Matzken ${ }^{12}$ ) spreckt van negatieve en van positieve invloeden op de interne controle door het gebruik van ponskaarten en computers.

Als een negatieve invloed merkt hij aan de eenmalige vastlegging en een herhaald gebruik daarvan voor verschillende doeleinden, hetgeen tot afgeleid werk voert. Accuratessecontroles op deze eerste vastlegging door controleponsen en het vervaardigen van controlestaten acht hij onvoldoende. Ter versterking van de interne controle beveelt hij aan het voeren van paralleladministraties (beide ponskaarten vanaf verschillende gronddokumenten), detailcontrole op de vastlegging in de ponskaart en totalencontrole op de verwerking van gronddokumenten en ponskaarten.

Als positieve invloeden op de interne controle noemt hij de scherpere functiescheiding en betere en snellere berichtgeving. Het gevaar dat de machinebediende het resultaat van de bewerkingen zal beïnvloeden acht hij niet groot, omdat deze niet met beheer en bewaring te maken heeft.

Van groot belang acht hij een onafhankelijke controleafdeling, welke in nauw contact met de bedrijfsleiding de voorbereiding en controle van de mechanische bewerkingen verzorgt.

Frielink ziet wel een gevaar in de beïnvloeding van de uitkomsten van de machine door de machinebediende. Hij zegt het volgende ${ }^{2}$ ):

'Indien een groot deel van de routinebeslissingen op grond van een uit-

m a b blz. 29 
gebreid en ingewikkeld programma wordt gefaktualiseerd door de automatiseringsapparatuur, is er

a. geen sprake meer van splitsing van de afhandeling van een transactie over verschillende employé's;

b. een vermenging van beheersfunctie en registrerende functie.'

En even verder:

'De huidige automatiseringsapparatuur bevat een uitgebreid arsenaal van middelen ter verzekering van de accuratesse van de verwerking, doch weinig of geen mogelijkheden tot het signaleren van bewust aangebrachte onjuistheden (frauduleuze ingrepen).'

$\mathrm{Hij}$ beveelt aan de computers uit te rusten met enige technische voorzieningen, te weten:

- het zogenaamde automatische logboek, waaronder is te verstaan een inrichting, waardoor automatisch elk gebruik van een programma en elke ingreep door de operateur onuitwisbaar worden geregistreerd, met vermelding van de bijzonderheden die voor een beoordeling uit een oogpunt van interne controle van betekenis zijn.

- zodanige beveiliging met sloten, dat het in werking stellen van de machine of het verrichten van bepaalde soorten van bewerkingen slechts kan worden uitgevoerd door daartoe bevoegde personen die in het bezit zijn van de betrokken sleutel en wier identificatieteken automatisch in de machine of in het logboek wordt vastgelegd.

Matzken ${ }^{12}$ ) en ook Frielink ${ }^{2}$ ) bevelen aan de (interne) accountant vroegtijdig bij de automatisering in te schakelen, teneinde de zorg voor een voldoende interne controle op zich te nemen. Frielink zegt dat de volledige beheersing van de conceptie van interne controle daarom van zo grote betekenis is, omdat vele vertrouwde interne controlemiddelen bij geïntegreerde informatieverwerking zullen wegvallen. Hiervoor zullen andere middelen in de plaats moeten worden gesteld en dit kan alleen door degene die zich het begrip volledig heeft eigen gemaakt en niet afhankelijk is van de bij wijze van recepten geleerde praktische mogelijkheden.

\section{Slotbeschowwing}

Het vraagstuk van de betekenis van de moderne administratieve techniek voor de administratie heeft zeer vele kanten. Enige daarvan en naar wij menen de belangrijkste hebben wij hiervoor nader besproken.

Hoewel de nieuwe techniek de functie van de administratie niet rechtstreeks beïnvloedt, is zij toch wel van wezenlijk belang voor de betere vervulling van die functie.

De geïntegreerde verwerking van administratieve gegevens met grote snelheid leidt tot een tijdwinst, en door het sneller ter beschikking stellen van de gegevens wint de administratie aan betekenis en dus aan waarde. Deze laatste opmerking is afkomstig van Van Belkum/Van der Meer ${ }^{3}$ ); hierna vervolgen zij:

'Van nog meer belang is wellicht dat de grotere snelheid ook in staat stelt gegevens te verkrijgen, waartoe tot op heden geen - praktisch realiseerbare - mogelijkheid bestond, omdat de opstelling teveel tijd zou heb- 
ben gevergd. Dit betreft niet alleen de betere hantering en de verdergaande analyse van het in de basisgegevens aanwezige ciffermateriaal, doch bijvoorbeeld ook de verwerking van externe statistische gegevens en voorts de tocpassing van de zogenaande ,operational research".'

Frielink ${ }^{2}$ ) noemt deze techniek met een meer algemene term de techniek voor het oplossen van combinatorische problemen. Hij zegt hiervan het volgende:

'Deze problemen hebben tot gemeenschappelijk kenmerk, dat de naar een bepaald kriterium gerekende, beste combinatie van een aantal factoren moet worden gekozen uit alle mogelijke combinaties, terwijl er geen rekenregels (algoritmen) gevonden kunnen worden om uit de kenmerken van een combinatie af te leiden hoe een betere combinatie moet zijn samengesteld, respectievelijk hoe de beste combinatie er uit zal zien.'

Bij een betrekkelijk gering antal variabelen is het zelfs met de huidige enorm snelle machines onmogelijk om binnen een redelijke tijd alle theoretische mogelijkheden te bepalen, teneinde de meest gunstige daaruit te kiezen. Als een opgave voor de tockomst ziet hij nog de ontwikkeling van wetenschappelijke zoekmethoden, ter oplossing van deze vraagstukken.

Nu wij toch reeds een blik op de toekomst hebben geworpen is het wellicht dienstig de verwachtingen van enige deskundigen na te gaan inzake de verdere ontwikkeling van de moderne apparatuur.

Een beperking van de huidige apparatuur is nog, dat deze uitsluitend machinetaal kan lezen. De ontwikkeling schijnt nu in twee richtingen te gaan, namelijk: enerzijds worden de machines geschikt gemaakt voor het lezen van handschrift of her opnemen van gesproken gegevens, anderzijds wordt nog getracht de primaire vastlegging direct in machinetaal te doen plaatsvinden (automatische produktieregistratie).

Deze grondgegevens worden in code via een bekabeling naar de verwerkingsapparatuur geleid, terwijl ook de informatic die als resultaat na de verwerking beschikbaar komt op gelijke wijze wordt getransporteerd naar de gebruikers.

Meeuwis ${ }^{10}$ ) verwacht door de snelle geauromeerde verwerking en door de opvoering van de frequentie van deze verwerlking, dat gegevenstransport naar respectievelijk van de verwerkingscentrale meer en meer een bottle-neck zal blijken te zijn.

Met een korte beschrijving van de toekomstverwachtingen zoals die door Unk ${ }^{18}$ ) worden gezien menen wij dit gedeelte te mogen afsluiten.

Hij wijst erop, dat slechts de steeds grotere en meer gecompliceerde systemen de voordelen kunnen bieden van:

snelle reaktie op individuele vragen door individuele informatieverwerking

- soepelheid in de programmering (general purpose computers)

- vereenvoudiging van de programmering (autocodes)

- verhoging van de efficiency

Deze machines zullen slechts door enkele grote gebruikers voldoende zijn te belasten. De kleinere en kleine gebruikers zijn dus anngewezen op gemeenschappelijk gebruik. Daarbij doen zich vraagstukken voor van prioriteit, geheimhouding der gegevens, telecommunicatie, en dergelijke. Hij verwacht dat 
op de duur grote systemen zullen verschijnen die door vele gebruikers gemeenschappelijk gebruikt zullen worden. Het is ook te verwachten, dat de gebruikers hierbij directe automatische aansluiting zullen krijgen door middel van telecommunicatienetten, zodat bij de gebruiker alleen individuele periferieapparatuur nodig is. Indien de periferie-apparatuur zodanig ontwikkeld kan worden dat deze tegen zeer lage prijs te verkrijgen is, zal het centraal systeem ook belast kunnen worden met zeer eenvoudige opgaven, waardoor ook een deel van de huidige hulpmachines voor tellen en rekenen zullen verdwijnen.

Naar zijn mening is het geen grote fantasie te veronderstellen dat over een termijn van ongeveer tien jaar de aansluiting aan een centraal informatieverwerkend systeem iets vanzelfsprekends zal zijn.

Onzes inziens mogen wij met vertrouwen de hier geschetste toekomst tegemoet zien; wij menen te mogen aannemen, dat ook in deze geheel nieuwe situatie de voordelen voor de administratie belangrijker zullen zijn dan de nadelen, en dat de administratie dan weer over betere gereedschappen zal beschikken om haar functie te vervullen. 
1. Kosten, Prof. Dr. Ir. L.,

Oberman, Prof. Dr. Ir. M. M. en

Reinoud, $\mathrm{H}$.

2. Frielink, A. B.

3. van Belkum, J. W. en

van der Meer, Th. J.

4. Willemze, Ir. F. G.

5. Becker, R. en

Murphy, E. F.

6. Levin, H. S.

(vertaling W. J. van Hoek)

7. Mulder, J. F. en van Oorschot, J. M.

8. Foppe, H. H. M.

9. Blazer, C. A.

10. Meeuwis, A.

11. van Duivenboden, F. G.

12. Matzken, R. H.

13. Kruisinga, Prof. Dr. H. J.

14. Klijnveld, P.

15. Laubach, P. B.
Enige aspecten van de elektronische verwerking van administratieve gegevens

De Accountant 1956

De administratieve automatisering als fase in de ontwikkeling der administratieve organisatie

De Accountant 1961

Toepassing van elektronica in de administratie (1959)

Automation: a new management problem M.A.B. 1958

The office in transition (1957)

Administratie en automatisering (1959)

Grondslagen van de administratieve automatisering (1959)

Enkele beschouwingen over de hulpmiddelen ten dienste der administratieve organisatie (1960)

Het gebruik van machinale hulpmiddelen in de administratie en de invloed daarvan op de controle (1928)

Prae-advies Accountantsdag 1928

Aanpak van automatie in de administratie, onderdeel van de Stumoka/Philips uitgave: Omschakeling naar Automatie (1960) en het bijbehorende verslag van de Stumokabijeenkomst

Electronic Computers

M.A.B. 1959

De invloed van de mechanische administratie op de accountantscontrole

M.A.B. 1958

Het gebruik van elektronische rekenmachines voor informatieverwerking - zijn de wittebroodsweken voorbij?

M.A.B. 1959

De machine in de moderne administratie (1922)

Company investigations of automatic data processing (1957) 
16. Smith, G. M.

17. Verbond van Prot./Chr. Werkgevers in Nederland,

Bavinck, Drs. J. G.

18. Unk, Prof. Ir. J. M.

19. Diebold, J.

(vertaling Ir. P. C. Snorn)
Office automation and white collar employment (1959)

Automatisering: het sociale aspect (1956)

Automatisering van administratieve en rekenkundige processen (1961)

Automatie (1957) 